\title{
Sigma Receptors Regulate Contractions of the Guinea Pig lleum Longitudinal Muscle/Myenteric Plexus Preparation Elicited by Both Electrical Stimulation and Exogenous Serotonin
}

\author{
Bruce G. Campbell, ${ }^{1}$ Michael W. Scherz, ${ }^{2}$ John F.W. Keana, ${ }^{2}$ and Eckard Weber ${ }^{1}$ \\ 'Vollum Institute, Oregon Health Sciences University, Portland, Oregon 97201, and 2Department of Chemistry, University \\ of Oregon, Eugene, Oregon 94305
}

Sigma receptors are specific, highly localized binding sites in limbic and sensorimotor structures of the brain that interact with many psychotropic drugs. These agents include the psychotomimetic benzomorphan opiates, the psychotomimetic drug phencyclidine and its analogs, as well as numerous typical and atypical antipsychotics such as haloperidol, chlorpromazine, and the novel drugs BMY 14802 and rimcazole. So far, no physiological function has been assigned to these binding sites. We have synthesized a number of novel sigma receptor-active drugs derived from the selective sigma ligand $N, N^{\prime}$-di(o-tolyl)guanidine (DTG). DTG and its congeners were found to inhibit contractions of the guinea pig ileal longitudinal muscle/myenteric plexus (LMMP) preparation evoked by electrical stimulation. In addition, the sigma ligands noncompetitively antagonized contractions of the LMMP preparation evoked by serotonin (5-HT). The 5-HT-evoked contractions were found to be largely due to 5-HT's activation of $5-\mathrm{HT}_{3}$ receptors to release ACh. The activity of DTG congeners in inhibiting electrically or 5-HT-evoked contractions of the LMMP highly correlated with their potency to inhibit binding of both ${ }^{3} \mathrm{H}-\mathrm{DTG}$ and $(+)^{3} \mathrm{H}-3$ PPP [3(3-OH-phenyl)-N-(1-propyl)piperidine] to sigma receptors in guinea pig brain homogenates. Two DTG congeners that did not bind to sigma receptors also showed no activity in the bioassay. Many other (but not all) sigma receptor ligands showed a high correlation between their potency to inhibit electrically evoked contractions of the LMMP and their sigma receptor binding affinity. The benzomorphans (+)SKF 10,047 and (+)cyclazocine potentlated electrically evoked contractions of the LMMP. Sigma ligands also inhibited the contractions of the LMMP in the presence of the opiate antagonist naloxone and in preparations in which opioid receptors had been inactivated by treatment with the irreversible opiate antagonist beta-chlornaltrexamine. Control experiments suggested that the sigma ligands act via a neuronal mechanism to inhibit ACh release evoked by electrical stimulation or by stimulation with $5-\mathrm{HT}$.

\footnotetext{
Received Oct. 14, 1988; revised Mar. 6, 1989; accepted Mar. 20, 1989.

We thank Barbara Tester and Nam Hoang for help with the binding assays, Dr. Annmarie Surprenant for providing guinea pig ilea, and Dr. John Williams for comments on the manuscript. This work was supported by grants from the National Institute of Mental Health (MH40303 and MH42068) and by a grant from Cambridge NeuroScience Research, Inc., Cambridge, MA

Correspondence should be addressed to Eckard Weber, M.D., Department of Pharmacology, University of California, Irvine, Irvine, CA 92717.

Copyright (C) 1989 Society for Neuroscience $0270-6474 / 89 / 103380-12 \$ 02.00 / 0$
}

These results suggest that there are functional sigma receptors on cholinergic nerve terminals or within the myenteric plexus and that these receptors can inhibit stimulated ACh release through an opioid receptor-independent mechanism. However, sigma receptor activation in the ileum has the same effect on $A C h$ release as activation of naloxonesensitive opioid receptors. The LMMP may be an in vitro bioassay system for characterizing the mechanism of action of sigma receptors and for determining the biological efficacy of drugs known to bind to sigma receptors in radioligand binding assays.

Phencyclidine (PCP, "angel dust") and certain benzomorphan (sigma) opiates have similar behavioral effects in humans and in animals (Holtzman, 1985; Katz ct al., 1985). In humans, these drugs are known to induce psychotomimetic effects similar to those seen in schizophrenic psychosis (Keats and Telford, 1964; Haertzen, 1970). Psychotomimetic effects are best documented for PCP since it is a widely abused street drug (Aniline and Pitts, 1982). Because of its strong psychotomimetic effects in humans, PCP has been proposed as a drug model for schizophrenia (Snyder, 1980). Recent radioligand binding studies have shown that in brain membrane homogenates PCP and sigma opiates bind to 2 anatomically and biochemically distinct receptor binding sites: the PCP receptor and the sigma receptor (Quirion et al., 1987; Sonders et al., 1988). The 2 receptors share some pharmacological properties in that they both bind PCP and its derivatives as well as the sigma opiates. However, the PCP receptor has a higher affinity for PCP than for sigma opiates, while the sigma receptor has a higher affinity for sigma opiates than for PCP (Largent et al., 1984, 1986; Downes et al., 1986; Weber et al., 1986). The main pharmacological difference between the 2 receptors is that sigma sites bind many typical and atypical antipsychotic drugs, while PCP receptors are insensitive to antipsychotics (Su, 1982; Largent et al., 1984, 1986, 1988; Tam and Cook, 1984; Weber et al., 1986). It has been proposed that PCP receptors are solely responsible for mediating the psychotomimctic cffects of PCP and sigma opiates (Sircar et al., 1986), while sigma receptors-because of their high affinity for many typical and atypical antipsychotic drugs - have been suggested as a site involved in mediating some of the therapeutic properties of the antipsychotic drugs that bind to this site (Deutch et al., 1988; Snyder and Largent, 1989).

Because of the proposed involvement of the 2 receptors in psychotomimetic and antipsychotic drug action, it is very important to establish the role of the 2 receptors in neuronal func- 
tion (Sonders et al., 1988). Recent work has unequivocally shown that the PCP receptor is associated with the $N$-methyl-D-aspartate (NMDA)-type glutamate receptor. Drugs that bind to the PCP receptor block the NMDA receptor-associated cation channel after it has been opened by NMDA receptor agonists (Anis et al., 1983; Wong et al., 1986; Kemp et al., 1987; Huettner and Bean, 1988), and the CNS distributions of PCP and NMDA sites are nearly identical (Maragos et al., 1988). Unlike for the PCP receptor, no physiological function has been established for the sigma receptor, although there is some evidence that sigma receptor-selective drugs can modulate neurotransmitter release (Campbell et al., 1987), interfere with central control of motor activity (Bowen et al., 1988b; Walker et al., 1988), and modulate phosphoinositide metabolism (Bowen et al., 1988a). Systematic investigations into the function of sigma receptors have been hampered by the lack of a wide spectrum of selective sigma receptor ligands and by the lack of an in vitro bioassay system in which to study sigma receptor function.

We have recently synthesized and characterized what appears to be the most selective radioligand for sigma receptors identified to date (Weber et al., 1986). This compound, ${ }^{3} \mathrm{H}-\mathrm{DTG}$ $\left(N, N^{\prime}-\operatorname{di}\left(2-\left[5-{ }^{3} \mathrm{H}\right]\right.\right.$ tolyl)guanidine), is a symmetrically substituted guanidine derivative. Structure-activity studies on compounds synthesized in our laboratories have shown that numerous analogs of DTG have a similar sigma receptor binding activity as the parent compound (unpublished observations). We report here that DTG and 9 analogs with potent sigma receptor affinity dose-dependently and by a neuronal mechanism inhibit muscle contractions of the isolated guinea pig ileum longitudinal muscle/myenteric plexus (LMMP) preparation evoked by electrical stimulation. Two additional disubstituted guanidines with very low sigma receptor affinity do not inhibit the electrically stimulated contractions of the LMMP. Additionally, we report here that DTG and its congeners with high sigma receptor affinity noncompetitively inhibit contractions of the LMMP evoked by stimulation of neuronal $5-\mathrm{HT}_{3}$ receptors by serotonin (5-HT). The potency of the DTG analogs in the 2 bioassays correlates highly with their potency to inhibit binding of ${ }^{3} \mathrm{H}-\mathrm{DTG}$ to sigma receptors in guinea pig brain homogenates, suggesting the presence of functionally active sigma receptors in the LMMP and a modulatory role for sigma receptors in neurotransmission in the myenteric plexus.

The guinea pig LMMP has served as a well-characterized bioassay for opioid receptors in which agonists at mu and kappa receptors inhibit the release of $\mathrm{ACh}$ from myenteric plexus neurons that have been excited by a brief electrical stimulus (Leslie, 1987). Activity at opioid receptors can be distinguished from that at sigma receptors by sensitivity to the opiate antagonist naloxone and by higher potency of opioid responses for the (-)benzomorphans compared with the (+)benzomorphans; sigma receptors are insensitive to naloxone and have the reverse stereoselectivity. We show here that the same functional response (inhibition of electrically stimulated contractions of the LMMP) can result from activation of opioid and of sigma receptors and that bioactivity of the (-)benzomorphans at sigma receptors can be demonstrated in tissues in which opioid receptors are blocked.

The results reported here may prove useful in the further understanding of sigma receptor function in 2 principal ways. First, a robust, easily performed bioassay is described that demonstrates a functional response mediated by sigma receptors and provides a means to determine if novel compounds possess sigma receptor bioactivity. Second, a series of novel compounds is described that includes compounds of high sigma receptor binding affinity and structurally related control compounds of very low sigma receptor affinity and bioactivity. These compounds may prove useful in the characterization of sigma receptor-mediated responses in the CNS and prove valuable in the development of sigma receptor-active pharmaceuticals.

\section{Materials and Methods}

Sigma receptor binding assays. Sigma receptor binding assays using guinea pig brain membrane homogenates and the radioligands ${ }^{3} \mathrm{H}-\mathrm{DTG}$ and $(+)^{3} \mathrm{H}-3-P P P$ were done as previously described (Weber et al., 1986). Briefly, frozen whole guinea pig brains (Biotrol, Indianapolis, IN) were homogenized in 10 volumes (wt/vol) of ice-cold $320 \mathrm{~mm}$ sucrose using a Brinkman polytron. The homogenate was centrifuged at $1000 \times g$ for $20 \mathrm{~min}$ at $4^{\circ} \mathrm{C}$. The supernatant was centrifuged at $20,000 \times g$ for $20 \mathrm{~min}$ at $4^{\circ} \mathrm{C}$. The resulting pellet was resuspended in 10 initial volumes of $50 \mathrm{~mm}$ Tris/ $\mathrm{HCl}$ buffer at $\mathrm{pH} 7.4$ and centrifuged at $20,000 \times g$ for $20 \mathrm{~min}$ at $4^{\circ} \mathrm{C}$. The resulting pellet was resuspended in 5 initial volumes ice-cold $50 \mathrm{~mm}$ Tris/ $\mathrm{HCl}(\mathrm{pH} \mathrm{7.4)}$, and the final volume was adjusted to yield a protein concentration of $3 \mathrm{mg} / \mathrm{ml}$, as determined by dye-binding protein assay (Biorad) using BSA as the standard. Aliquots of $20 \mathrm{ml}$ were stored at $-70^{\circ} \mathrm{C}$ until used, with no detectable loss of binding.

For ${ }^{3} \mathrm{H}$-DTG binding assays, $20 \mathrm{ml}$ aliquots of the frozen membrane suspension were thawed and diluted $1: 3$ in $50 \mathrm{~mm}$ Tris/ $\mathrm{HCl}(\mathrm{pH} \mathrm{7.4)}$. To $12 \times 75 \mathrm{~mm}$ polystyrene test tubes were added $0.8 \mathrm{ml}$ of diluted membrane suspension, $0.1 \mathrm{ml}$ of ${ }^{3} \mathrm{H}-\mathrm{DTG}$ ( $46 \mathrm{Ci} / \mathrm{mmol}$; see Weber et

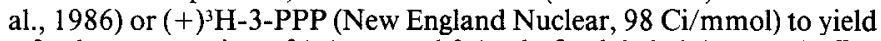
a final concentration of $1.4 \mathrm{nM}$, and $0.1 \mathrm{ml}$ of unlabeled drugs or buffer. The protein concentration in the $1 \mathrm{ml}$ final incubation volume was 800 $\mu \mathrm{g} / \mathrm{ml}$, corresponding to $32 \mathrm{mg}$ of hrain tissue (original wet weight) and to a tissue concentration within the linear range for specific binding. Nonspecific binding was defined as that remaining in the presence of $10 \mu \mathrm{M}$ haloperidol. Specific binding constituted $>90 \%$ of total ${ }^{3} \mathrm{H}$-DTG binding. Incubations were terminated after $90 \mathrm{~min}$ at room temperature by addition of $4 \mathrm{ml}$ of ice-cold $50 \mathrm{~mm}$ Tris/ $\mathrm{HCl}(\mathrm{pH} \mathrm{7.4)}$ and rapid filtration of the membrane suspension through Whatman $\mathrm{GF} / \mathrm{B}$ glassfiber filters under vacuum, using a 48 well cell harvester (Brandel, Gaithersburg, MD). The filters were washed 2 times with $4 \mathrm{ml}$ of $50 \mathrm{~mm}$ Tris/ $\mathrm{HCl}$ (pH 7.4). Total filtration and washing time was less than $20 \mathrm{sec}$. Each filter was dissolved in $10 \mathrm{ml}$ Cytoscint (Westchem, San Diego, $\mathrm{CA}$ ), and radioactivity was measured by liquid scintillation spectrometry at a counting efficiency of approximately $50 \%$. IC $_{50}$ values were determined by interpolation from displacement-curve plots on semilogarithmic graph paper.

Preparation of guinea pig ileum longitudinal muscle strips. Male Hartley guinea pigs (225-300 gm; Charles River Breeders, MA) were killed by a blow to the head and exsanguinated. A length of small intestine between $10 \mathrm{~cm}$ and $25 \mathrm{~cm}$ proximal to the ileocecal junction was removed, and its lumen was gently flushed with a Krebs solution of the following composition (mM): $\mathrm{NaCl}, 118 ; \mathrm{KCl}, 4.75 ; \mathrm{CaCl}_{2}, 2.54 ; \mathrm{MgCl}_{2}$, 1.17; $\mathrm{NaHCO}_{3}, 25.0 ; \mathrm{KH}_{2} \mathrm{PO}_{4}, 0.93$; and D-glucose, 11.0. Strips of 2 $\mathrm{cm}$ length were stretched over a Lucite rod, the mesentery carefully removed, and the longitudinal muscle layer with adherent myenteric plexus separated from the underlying circular muscle by gently stroking tangentially away from the mesenteric attachment with a cotton-tipped applicator. These longitudinal muscle strips were mounted in $5 \mathrm{ml}$ organ baths containing Krebs solution at $37^{\circ} \mathrm{C}$ and bubbled with $5 \%$ carbon dioxide in oxygen. The strips were placed under a resting tension of 500 mg. Contractions were recorded isometrically with Grass FT .03C transducers connected to Grass $79 \mathrm{D}$ polygraphs.

Electrically stimulated longitudinal muscle strips. The strips were stimulated by a Grass $\mathrm{S} 88$ stimulator at $0.5 \mathrm{~Hz}$ (supramaximal voltage, $1 \mathrm{msec}$ duration) via platinum ring electrodes $3.0 \mathrm{~cm}$ apart. An equilibration pcriod of $90 \mathrm{~min}$ was allowed beforc testing, with frequent exchange of the bathing solution by overflow. Compounds were administered by microliter syringe injections of $\leq 10 \mu \mathrm{l}$ and were left in contact with the tissues until the response stabilized. The effect of compounds on the electrically stimulated twitch was measured as the ratio of the twitch amplitude in the presence of the compound to that immediately prior to its addition. Intervals of at least $30 \mathrm{~min}$ (with frequent bathing solution changes) were allowed between single doses, during 
which contractions returned to their previous amplitude. Antagonists were allowed to preequilibrate for at least $10 \mathrm{~min}$ prior to addition of test compound. The half-maximal inhibitory concentration $\left(\mathrm{IC}_{50}\right)$ for a drug in a given tissue was estimated by interpolation from a log-concentration curve which contained 3 or 4 concentrations within the range of $20-80 \%$ of maximal effect. The geometric mean of 4 or more of these values was obtained as an estimate of the $\mathrm{IC}_{50}$ of the compound in inhibiting the electrically evoked twitch. Differences between 2 mean ${ }_{\text {IC }}$ values were analyzed by Student's $t$ test.

In some experiments, naloxone was included in the Krebs buffer during the entire experiment. In other experiments, the strips were treated with beta-chlornaltrexamine (B-CNA, an irreversible opiate receptor antagonist), as follows. After the equilibration period, a concentration response curve to 2-D-Ala-Glyol-Met-enkephalin (DAGO) or $\mathrm{U} 50,488 \mathrm{H}$ was ubtained. B-CNA was injected into the bathing solution of each strip to yield a concentration of $100 \mathrm{nM}$, and the strips were incubated for $30 \mathrm{~min}$. The strips were extensively washed by repeatedly changing the bathing solution, and $\mathrm{B}-\mathrm{CNA}$ was injected a second time to yield a concentration of $100 \mathrm{nM}$. After 30 min incubation, the strips were washed extensively for $45 \mathrm{~min}$. Only tissues in which $1 \mu \mathrm{M}$ concentrations of DAGO and of U50,488H elicited no change in twitch amplitude subsequent to B-CNA treatment were used.

Agonist-stimulated longitudinal muscle strips. In experiments employing 5-HT as agonist, $1 \mu \mathrm{M}$ methysergide or $1 \mu \mathrm{M}$ ketanserin was included in the Krebs buffer during the entire experiment. Following the $90 \mathrm{~min}$ equilibration period, 3 noncumulative concentration-response curves for 5 -HT were obtained, the first and third in Krebs buffer and the second in Krebs buffer containing a concentration of a compound tested as an antagonist, as follows. 5-HT was added to each organ bath by microliter syringe and remained in contact with the strips for $1 \mathrm{~min}$. The maximum height of the resulting contraction was recorded for each concentration of 5-HT. An interval of $20 \mathrm{~min}$ between 5-HT applications was allowed during which the strips were washed extensively; preliminary experiments determined that this procedure avoided tachyphylaxis of 5-HT responses. Concentrations of 5-HT over the range $20 \mathrm{nM}$ to $60 \mu \mathrm{M}$ were tested at half-log intervals and were applied in a varying, random sequence. A second concentration-response curve to 5-HT was obtained in the presence of an antagonist. The antagonist had been added to the Krebs buffer and was present during a $30 \mathrm{~min}$ equilibration period prior to and during the second 5-HT concentrationresponse curve. Concentrations of 5-HT were tested until no further increase in the evoked-twitch amplitude was observed. The strips were washed extensively for $30 \mathrm{~min}$ in normal Krebs before the third 5-HT concentration-response curve was obtained. Only strips for which the maximum twitch heights obtained during the first and third concentration-response curves differed by $\leq 10 \%$ were used. For each strip individually the maximum response to 5-HT obtained during the second 5-HT concentration-response curve was divided by the mean of that obtained in the first and third concentration-response curves, and for each concentration of antagonist, the percentage values thus obtained from several preparations were expressed as a mean value. A concentration-response curve for the antagonist was constructed from independent measures for each antagonist concentration. In other experiments, bethanachol (a muscarinic agonist) or 2-methyl-5-HT (with 1 $\mu_{\mathrm{M}}$ methysergide present during the entire experiment) were used a agonists in the 3-concentration-response curve paradigm as detailed above for 5-IIT. In other experiments, DTG, $(+) 3-P P P$, and $(+)$ SKF 10,047 were employed as agonists in a single concentration-response curve paradigm.

Drugs used. B-CNA (RBI) was dissolved in anhydrous ethanol acidified with glacial acetic acid and used immediately for each application. 5- $\mathrm{HT} \mathrm{HCl}$ (Sigma) was dissolved in $\mathrm{H}_{2} \mathrm{O}$ on each day of use and kept on ice in light-tight test tubes during the experiment. The following compounds were dissolved in dilute $\mathrm{HCl}$, brought up in $\mathrm{H}_{2} \mathrm{O}$, and titrated to $\mathrm{pH} 7$ with dilute $\mathrm{NaOH}$ : DTG and disubstituted guanidines except AdIpG and Bridge-DPG (see below), $(+)$ and ( - )pentazocine (Sterling Winthrop), and MK-801 maleate (Merck). Haloperidol (McNeil), (-)sulpiride, and perphenazine (Sigma); $(+)$ and $(-$ )cyclazocine (Sterling Winthrop); spiperone (RBI); and AdIpG and BridgeDPG were dissolved in methanol. 5-HTP-DP ( $N$-acetyl-5-hydroxytryptophyl-5-hydroxytryptophan amide, gift of $\mathrm{A}$. Surprenant) was prepared on the day of use by dissolving it in a minimum volume of ethanol and diluting in Krebs buffer to a final concentration of $<10 \%$ ethanol. Bethanechol, atropine, hexamethonium, tetrodotoxin, chlorpromazine, and naloxone (Sigma); PCP $\mathrm{HCl}$ and TCP (NIDA); meth- ysergide, ketanserin, and ICS 205-930 (Sandoz); BMY 14802 and tiospirone (Mead Johnson); DAGO (Bachem); rimcazole (Burroughs Wellcome); 5-CT (5-carboxyamidotryptamine, Glaxo); (+) and (-)SKF 10,047 (Sterling Winthrop) and 8-OH-DPAT [8-(hydroxy-2-( $n$-dipropylamino)tetralin] and $(+)$ and $(-) 3$-PPP HCL (RBI) were dissolved in $\mathrm{H}_{2} \mathrm{O}$. Control injections using only the solvent vehicles (methanol and ethanol) had no effect on the electrically or 5-HT-evoked responses.

Eleven disubstituted guanidines (all structural analogs of DTG) were synthesized and purified by two of us (M.W.S., J.F.W.K.). The synthesis and chemical characterization of the compounds will be described elsewhere. See Figure 1 for their structure and its legend for their chemical names and the abbreviations used in this paper.

\section{Results}

\section{Binding of novel DTG analogs to sigma receptors}

${ }^{3} \mathrm{H}$-DTG has been shown to be a selective radioligand for sigma receptors in guinea pig brain (Weber et al., 1986). Eleven novel DTG analogs were synthesized and purified (Fig. 1; unpublished observations). Ninc of these compounds were found to be potent ligands of sigma receptors as determined by their ability to displace ${ }^{3} \mathrm{H}-\mathrm{DTG}$ from sigma receptors in guinea pig brain homogenates (Table 1); the most potent of these was AdIpG, with an $\mathrm{IC}_{50}$ of $6.2 \pm 0.7 \mathrm{nM}(n=3)$. These compounds also displaced the sigma receptor ligand $(+)^{3} \mathrm{H}-3-P P P$ with high affinity from guinea pig brain homogenates (data not shown), and there was a high correlation of $\mathrm{IC}_{50}$ values of these compounds in displacing the 2 sigma selective radioligands $(r=0.98, p<0.0001$; Fig. 2). Thus, these DTG analogs are potent sigma receptor ligands. Two of the compounds were inactive $\left(\mathrm{IC}_{50}>100 \mu \mathrm{M}\right)$ in displacing ${ }^{3} \mathrm{H}-\mathrm{DTG}$; these were the conformationally constrained congener Bridge-DPG and DMG (Fig. 1, Table 1). The inactive DTG congeners served as controls to evaluate nonspecific effects of disubstituted guanidines in the bioassays.

\section{Activity of novel DTG analogs and other sigma ligands on electrically stimulated longitudinal muscle strips}

The sigma receptor selective compound DTG inhibited the electrically evoked contractions of the guinea pig ileum LMMP preparation in a concentration-dependent manner with an $\mathrm{IC}_{50}$ of $3.1 \pm 0.3 \mu \mathrm{M}$ (Fig. $3 A$, Table 1). The time course of DTG's action in inhibiting contractions was slower than that of opioid receptor agonists, taking 3-10 min to reach maximum effect and 5-10 min for the tissue to recover completely to its prior contraction amplitude. In addition to DTG, 9 of the disubstituted guanidine compounds inhibited the electrically evoked contractions in a concentration-dependent manner (Table 1, Fig. $3 A$ ) in the presence of $1.25 \mu \mathrm{M}$ naloxone. The most potent congener was $\mathrm{AdIpG}$ with an $\mathrm{IC}_{50}$ of $1.0 \pm 0.2 \mu \mathrm{M}$ (Fig. $3 A$ ). The 2 DTG analogs that had no sigma receptor binding activity were also inactive in inhibiting the electrically evoked contractions of the muscle strips up to $100 \mu \mathrm{M}$; these were the conformationally constrained congener Bridge-DPG and DMG (Table 1).

Numerous other compounds with high affinity for the sigma receptor were tested for the ability to inhibit the electrically evoked contractions of the longitudinal muscle strips in the presence of $1.25 \mu \mathrm{M}$ naloxone. The sigma receptor selective compound $(+) 3$-PPP inhibited contractions in a concentrationdependent manner with an $\mathrm{IC}_{50}$ of $51.3 \pm 7.5 \mu \mathrm{M}$ (Table 1, Fig. $3 A$ ); the $\mathrm{IC}_{50}$ of $(-) 3-\mathrm{PPP}$ was $111 \pm 12 \mu \mathrm{M}$. The sigma-selective antipsychotic compounds BMY 14802 and rimcazole and the antipsychotic compounds with high sigma receptor affinity haloperidol, perphenazine, tiospirone, and chlorpromazine all inhibited the electrically evoked contractions in a concentration- 
Table 1. Sigma receptor binding and bioactivity of DTG, its congeners and other sigma receptor ligands

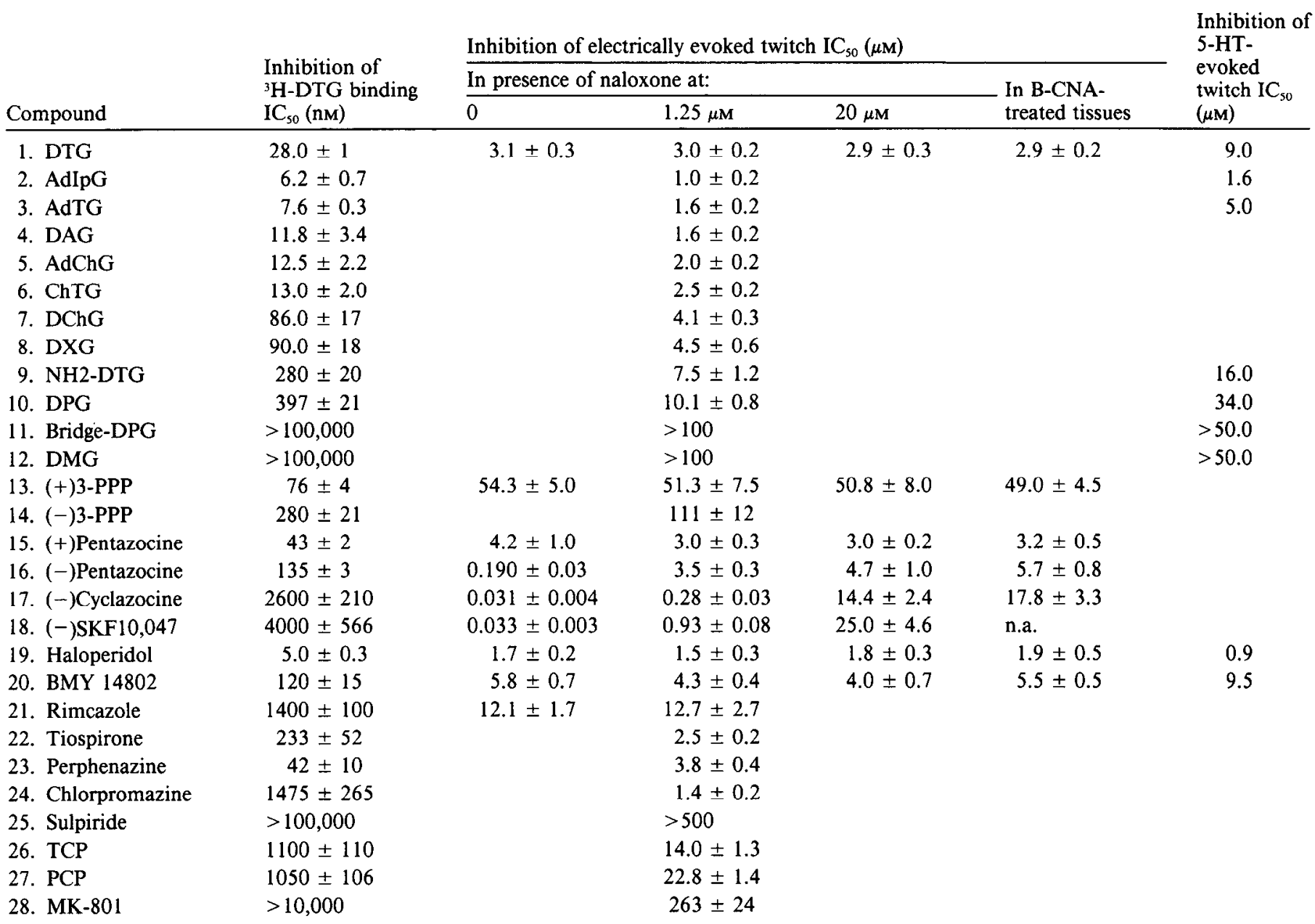

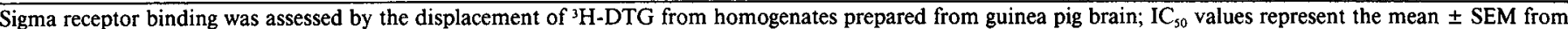

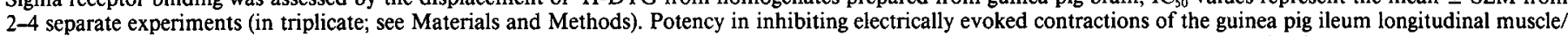

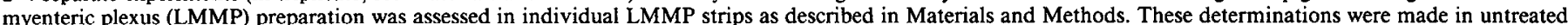

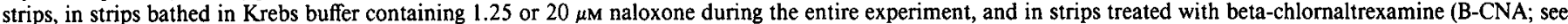
Materials and Methods). Potency in inhibiting 5-HT-evoked contractions was determined as described in Materials and Methods.

dependent manner (Table 1). The $\mathrm{D}_{2}$-selective antagonist $(-)$ sulpiride did not affect the electrically evoked contractions up to $500 \mu \mathrm{M}$. In addition, PCP and its analog 1-[1-(2-thienyl)cyclohexyl]piperidine (TCP), which have moderate affinities for sigma receptors but high affinities for PCP receptors, inhibited the electrically evoked contractions with moderate potency $\left(\mathrm{IC}_{50}=21.8 \pm 1.4\right.$ and $14.0 \pm 1.3 \mu \mathrm{M}$, respectively). On the other hand, the high-affinity PCP receptor ligand MK801 , which is very weak in displacing ${ }^{3} \mathrm{H}-\mathrm{DTG}$ at sigma receptors, was also very weak in inhibiting the twitch $\left(\mathrm{IC}_{50}=263 \pm\right.$ $12 \mu \mathrm{M})$, indicating that the inhibition in the ileum is not mediated by PCP receptors.

The inhibition of contractions by DTG and (+)3-PPP were not affected by preincubation of the longitudinal muscle strips with $10 \mu \mathrm{M}$ phentolamine, $1 \mu \mathrm{M}$ benoxathian, $1.25 \mu \mathrm{M}$ idazoxan, $40 \mu \mathrm{M}(-)$ sulpiride, or $1.25 \mu \mathrm{M}$ naloxone, suggesting the inhibition of the electrically evoked contractions was not mediated by alpha $a_{1}$ or alpha $a_{2}$ adrenergic, $D_{2}$ dopaminergic, or opioid receptors.
Actions of mixed opioid/sigma receptor active isomers of benzomorphans on the electrically stimulated muscle strips

(-)Isomers of benzomorphan opiates (pentazocine, cyclazocine, and SKF 10,047) active at both opioid and sigma receptors potently inhibited electrically evoked contractions of the longitudinal muscle strips in the absence of naloxone (Table 1). The concentration-response curves were shifted to the right in presence of $1.25 \mu \mathrm{M}$ naloxone and were shifted further to the right by $20 \mu \mathrm{M}$ naloxone (Table 1). Thus, the (-)benzomorphans seemed to inhibit the twitch primarily by interacting with naloxone-sensitive opioid receptors. The mu-opioid receptor-selective peptide $\mathrm{DAGO}$ inhibited contractions with an $\mathrm{IC}_{50}$ value of $11 \pm 1.0 \mathrm{nM}(n=4$; Fig. $3 B)$, in close agreement with published values (Traynor et al., 1987). DAGO's effects were competitively blocked by naloxone. The kappa-opioid receptor agonist $\mathrm{U} 50,488 \mathrm{H}$ inhibited contractions with an $\mathrm{IC}_{50}$ value of $10.0 \pm 0.2 \mathrm{~nm}(n=4)$.

In order to determine if $(-)$ benzomorphans can also inhibit 
<smiles>CC1=CCCCC1NC(=N)NC1CCC=CC1C</smiles><smiles>N=C(NC1CCC=CC1I)NC12CC3CC(CC(C3)C1)C2</smiles><smiles>CC1C=CCCC1NC(=N)NC12CC3CC(CC(C3)C1)C2</smiles><smiles>N=C(NC12CC3CC(CC(C3)C1)C2)NC12CC3CC(CC(C3)C1)C2</smiles><smiles>N=C(NC1CCCCC1)NC12CC3CC(CC(C3)C1)C2</smiles><smiles>N=C(NC1CCCCC1)NC1CCCC1</smiles>

7<smiles>CC1C=CCC[C@@H]1NC(=N)NC1CC[C@@H](N)C[C@H]1C</smiles><smiles>N=C1NC2C=CC=CC2C2CCCCC2N1</smiles>

11<smiles>CC1CCCC=C1NC(=N)NC1CCCCC1</smiles><smiles>CC1=C(NC(=N)NC2C(C)CCCC2C)[C@H](C)CCC1</smiles>

8<smiles>N=C(NC1=CCCCC1)Nc1ccccc1</smiles><smiles>CNC(=N)NC</smiles>

12

Figure 1. Structures of the sigma receptor-selective ligand DTG and the 11 congeners characterized in this study. Compounds $1-10$ are active in sigma receptor binding and bioassays; compounds 11 and 12 are sigma receptor-inactive control substances that are chemically related to the others. For each compounds pictured, the chemical name is given, followed by its abbreviation in parentheses. $1, N, N^{\prime}$-di(o-tolyl)guanidine (DTG);2, $N$-(2-iodophenyl)- $N^{\prime}$-(adamant-1-yl)guanidine (AdIpG); 3 $N$-(o-tolyl)- $N^{\prime}$-(adamant-1-yl)guanidine (AdTG); 4, $N, N^{\prime}$-di(adamant-1yl)guanidine (DAG); 5, $N$-(cyclohexyl)- $N^{\prime}$-(adamant-1-yl)guanidine (AdChG); 6, $N$-(o-tolyl)- $N^{\prime}$-(cyclohexyl)guanidine (ChTG); 7, $N, N^{\prime}$-dicyclohexyl)guanidine (DChG); $8, N, N^{\prime}$-di(2,6-methylphenyl)guanidine (DXG); $9, N$-(o-tolyl)- $N^{\prime}$-(4-amino-2-methylphenyl)guanidine $\left(\mathrm{NH}_{2}-\right.$ DTG); $10, N, N^{\prime}$-di(phenyl)guanidine (DPG); 11,2 -amino-1,3H-dibenzo[d,f]-[1,3]-diazepine (Bridge-DPG); 12, $N, N^{\prime}$-di(methyl)guanidine (DMG). Note that these numbers are used to identify DTG congeners in Table 1 and Figures 2 and $6 A, B$; the abbreviations are used in the text, table, and figure legends.

the twitch by interacting with sigma receptors, the longitudinal muscle strips were treated with the irreversible opioid receptor antagonist B-CNA twice for $30 \mathrm{~min}$ at $100 \mathrm{nM}$ in order to inactivate opioid receptors. In B-CNA-treated strips, DAGO was inactive at 1 and $5 \mu \mathrm{M}$ and inhibited contractions at $10 \mu \mathrm{M}$ by only $13 \%$ (Fig. $3 B$ ) and $U 50,488 \mathrm{H}$ was inactive at 1 and $5 \mu \mathrm{M}$, suggesting a virtual inactivation of opioid receptors. In B-CNAtreated strips $(-)$ cyclazocine and $(-)$ pentazocine inhibited contractions at $\mathrm{IC}_{50}$ values not statistically different from those

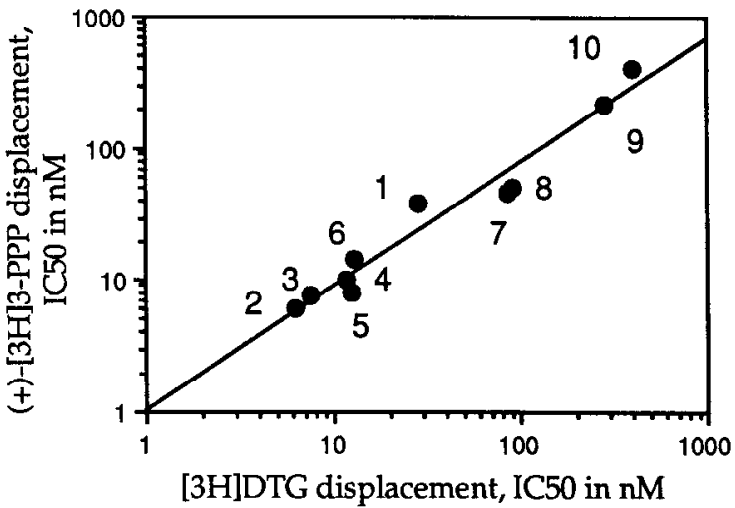

Figure 2. Correlation of sigma receptor binding affinitics of DTG and 9 congeners in radioligand binding assays using ${ }^{3} \mathrm{H}-\mathrm{DTG}$ and $(+) 3-{ }^{3} \mathrm{H}-$ 3-PPP to label sigma receptors. ${ }^{3} \mathrm{H}-\mathrm{DTG}$ assays were conducted as described in Materials and Methods, and $(+)-{ }^{3} \mathrm{H}-3-\mathrm{PPP}$ assays were conducted as described in Weber et al. (1986). The affinities of DTG (I) and 9 congeners $(2-10)$ as assessed in the 2 sigma receptor radioligand binding assays was highly correlated $(r=0.98, p<0.0001)$. All numbers as in Table 1 and Figure 1.

obtained in the presence of $20 \mu \mathrm{M}$ naloxone (Table 1). (-)SKF 10,047 in B-CNA-treated strips inhibited contractions with a flat concentration-response curve that did not reach $50 \%$ inhibition (data not shown). DTG, (+)pentazocine, (+)3-PPP, BMY 14802, and haloperidol inhibited contractions of the longitudinal muscle at $\mathrm{IC}_{50}$ values not statistically different in the absence of naloxone and in B-CNA-treated strips (Table 1, Fig. $3 B$ ). These results suggest that $(-)$ benzomorphans can inhibit the twitch by an opioid receptor-independent mechanism (presumably through action at sigma receptors), and they confirmed that the high-affinity sigma ligands DTG, $(+)$ pentazocine, $(+) 3$ PPP, BMY 14802, and haloperidol do not act through opioid receptors to inhibit the twitch.

Actions of sigma receptor active isomers of benzomorphans on the electrically evoked twitch response of the muscle strips

The sigma receptor active benzomorphan $(+)$ pentazocine inhibited the electrically evoked contractions of the longitudinal muscle strips with equal potency in the absence of naloxone and in the presence of 1.25 and $20 \mu \mathrm{M}$ naloxone (Table 1). Unlike all other sigma ligands, the benzomorphans (+)SKF 10,047 $[(+) \mathrm{N}$-allyl-normetazocine] and $(+)$ cyclazocine potentiated contractions of the electrically stimulated longitudinal muscle strips in a concentration-dependent manner. (+)SKF 10,047 caused a maximal increase in the twitch of $93 \%$ and the concentration that evoked $50 \%$ of this maximum $\left(\mathrm{EC}_{50}\right)$ was $3.2 \mu \mathrm{M}$ ( $n=16$, data not shown). Additionally, $(+)$ SKF 10,047 increased the basal tension of the electrically stimulated strips such that the baseline was elevated. The threshold detectable increase (defined as $50 \mathrm{mg}$ ) was $1.0 \mu \mathrm{M}$, and the increase was $570 \mathrm{mg}$ at $50 \mu \mathrm{M}$ (data not shown). Neither the twitch augmentation nor the baseline elevation was altered in the presence of $1.25 \mu \mathrm{M}$ naloxone or $500 \mathrm{nM}$ DTG, nor were they different in B-CNA-treated longitudinal muscle strips. (+)Cyclazocine increased the electrically stimulated contractions with a maximal increase of $41 \%$ with an $\mathrm{EC}_{50}$ of $1.4 \mu \mathrm{M}(n=8)$ and increased the resting tension with a threshold of $1 \mu \mathrm{M}$ and an increase of $145 \mathrm{mg}$ at $50 \mu \mathrm{M}(n=8)$. These effects of $(+)$ cyclazocine were not significantly different in B-CNA-treated strips. 
A

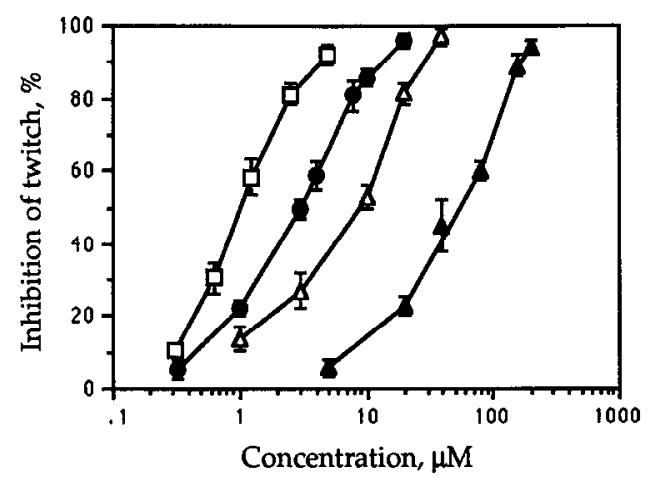

$\mathbf{B}$

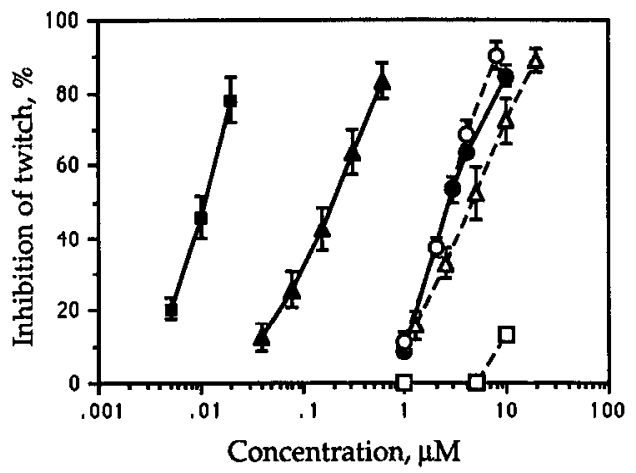

Figure 3. A, Inhibition of electrically evoked contractions of the guinea-pig longitudinal muscle/myenteric plexus (LMMP) preparation. AdIpG (open squares), DTG (filled circles), DPG (open triangles), and (+)3-PPP (filled triangles.). $B$, Inhibition of electrically evoked contractions of the LMMP prior to and following beta-chlornaltrexamine (B-CNA) treatment. Compounds were evaluated in the same tissues prior to (solid lines) and following B-CNA treatment (dashed lines), as described in Materials and Methods. DAGO before (filled squares) and after (open squares) B-CNA treatment, (-)pentazocine before (filled triangles) and after (open triangles) B-CNA treatment and DTG before (filled circles) and after (open circles) B-CNA treatment. In both $A$ and $B$, for each concentration tested, the effect is expressed as a percentage and plotted for the value (mean \pm SEM, $n=4-16$ ) one minus the ratio of the twitch amplitude in the presence of the compound to that immediately prior to its addition to the bathing solution.

\section{Activity of sigma receptor ligands on unstimulated longitudinal muscle strips}

DTG and (+)3-PPP did not affect the resting tension of longitudinal muscle strips at concentrations up to $100 \mu \mathrm{M}$, suggesting that the sigma ligands did not interact directly with the muscle to reduce resting tension. However, $(+)$ SKF 10,047 increased the resting tension of the longitudinal muscle strips in a concentration-dependent manner with a detectable threshold (defined as $50 \mathrm{mg}$ ) of $1 \mu \mathrm{M}$ and an increase of $500 \mathrm{mg}$ at $50 \mu \mathrm{M}$ (data not shown). This increase in resting tension was blocked by $1 \mu \mathrm{M}$ TTX and $1 \mu \mathrm{M}$ atropine. The increase in resting tension under unstimulated conditions was not statistically different from that observed during electrical stimulation.

\section{Activity of sigma ligands on muscle strip contractions evoked by a muscarinic agonist}

In order to determine whether sigma ligands acted directly on the muscle or on myenteric cholinergic neurons (or nerve terminals) to inhibit the electrically evoked contractions of the muscle strip, we tested the effects of sigma drugs on muscle contractions evoked by the muscarinic agonist bethanechol. Bethanechol evoked contractions of the longitudinal muscle strips with an $\mathrm{EC}_{50}$ of $2.2 \mu \mathrm{M}(n=12)$. These contractions were produced rapidly and maintained in the presence of agonist. The contractions were abolished in the presence of $1 \mu \mathrm{M}$ atropine but were not affected by $100 \mu \mathrm{M}$ hexamethonium or $1 \mu \mathrm{M}$ TTX. DTG at $50 \mu \mathrm{M},(+) 3-\mathrm{PPP}$ at $100 \mu \mathrm{M}$, and (+)SKF 10,047 at 10 $\mu \mathrm{M}$ did not affect the bethanechol concentration-response curve, suggesting that the sigma ligands did not act on the muscle or on muscarinic receptors to inhibit (or potentiate for SKF 10,047) the electrically evoked contractions of the muscle strips.

\section{Activity of sigma receptor ligands on 5-HT-stimulated longitudinal muscle strips}

The observations above support the hypothesis that sigma receptor ligands act by a neuronal mechanism to inhibit the electrically stimulated release of ACh that leads to LMMP contraction. To further characterize this mechanism, we investigated the ability of sigma ligands to inhibit the release of ACh stimulated by 5-HT. 5-HT has been shown to have multiple effects on myenteric neurons (see Furness and Costa, 1987; Takaki et al., 1985; Mawe et al., 1986; Galligan et al., 1988), to be capable of releasing ACh from the myenteric plexus (Adam-Vizi and Vizi, 1978; Kilbinger and Pfeuffer-Friederich, 1985), and to cause the LMMP to contract (Gaddum and Picarelli, 1957; Buchhcit ct al., 1985; Richardson ct al., 1985). In the presence of $1 \mu \mathrm{M}$ methysergide, 5-HT evoked contractions of the longitudinal muscle strips over a broad concentration range of 20 nм-60 $\mu$ M (Fig. 4A). Concentration-response curves were shallow and often notably biphasic with an inflection point near $500 \mathrm{~nm}$. 5-HT-evoked contractions below $500 \mathrm{~nm}$ constituted approximately $20 \%$ of the maximum response, were characterized by slow onset, and were maintained in the presence of agonist. 5-HT-evoked responses above $500 \mathrm{~nm}$ constituted the remaining $80 \%$ of the maximum response and were characterized by rapid climb to peak amplitude followed by a return to baseline, although the agonist continued to be present. The biphasic nature of the 5-HT concentration-response curve has previously been noted (Buchheit et al., 1985). Contractions evoked by 5 -HT were completely blocked by $1 \mu \mathrm{M}$ TTX, confirming their neuronal mediation.

The pharmacologic specificity of 5-HT's ability to contract the LMMP was assessed by examining the contractile effects of selective 5-HT receptor agonists and the contraction-inhibiting effects of antagonists. The selective 5- $\mathrm{HT}_{1 \mathrm{~A}}$ agonists 8-OH-DPAT and 5-CT at $1 \mu \mathrm{M}$ failed to alter the resting tension of the LMMP. 2-Methyl-5-HT, an full agonist at enteric $5-\mathrm{HT}_{3}$ receptors (Mawe et al., 1986; Surprenant and Crist, 1988), evoked contractions of the LMMP that plateaued at a maximal amplitude not statistically different than that which 5-HT evoked in the same preparation (Fig. $4 B$ ). The concentration-response curve for 2-methyl-5-HT was monophasic over a range of $1-100 \mu \mathrm{M}$ with an $\mathrm{EC}_{50}$ of $8.6 \mu \mathrm{M}$. Contractions evoked by 2 -methyl-5-HT were completely blocked by $1 \mu \mathrm{M}$ TTX (data not shown). Both the 5-HT and the 2-methyl-5-HT responses were obtained in the presence of $1 \mu \mathrm{M}$ methysergide to block $5-\mathrm{HT}_{2}$ receplors located on smooth muscle cells; similar results were obtained in the 
A

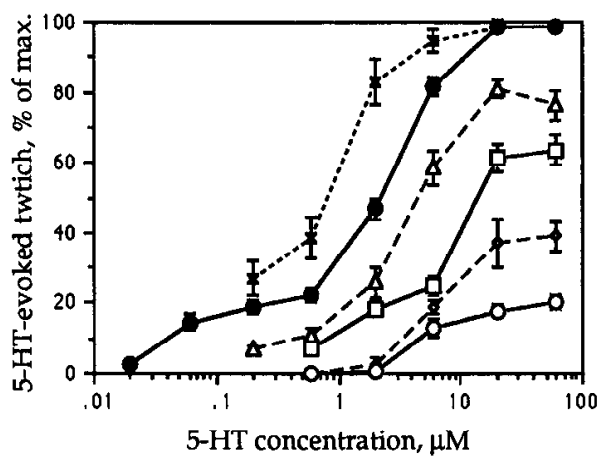

B

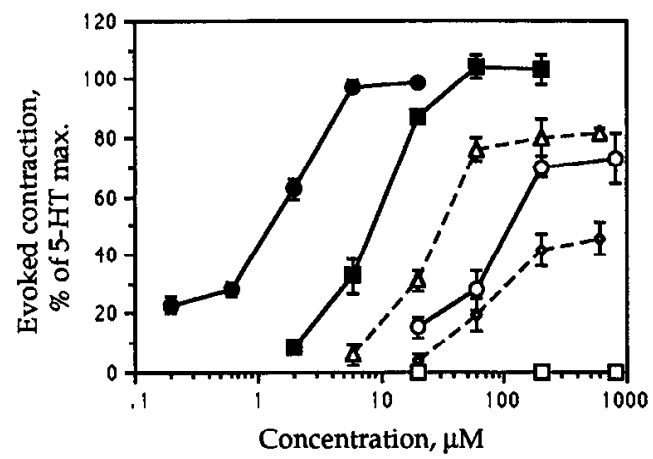

Figure 4. 5-HT-evoked contractions of the LMMP and the noncompetitive antagonism of this effect by $\mathrm{NH}_{2}-\mathrm{DTG}$ and the augmentation of this effect by (+)SKF 10,047. 5-HT evoked contractions of the LMMP over the range $20 \mathrm{nM}-60 \mu \mathrm{M}$ with a biphasic concentration-response curve (filled circles; see Results). Each of the following 5 curves represent independent experiments $(n=4$ each) employing the 3-concentration-response curve paradigm described in Materials and Methods. Four curves depict 5-HT-evoked contractions assayed in the presence of $4 \mu \mathrm{M} \mathrm{NH}_{2}$-DTG (open triangles), $10 \mu \mathrm{M} \mathrm{NH} \mathrm{NH}_{2}$-DTG (open squares), $20 \mu \mathrm{M} \mathrm{NH} \mathrm{NH}_{2}$-DTG (open diamonds), and $40 \mu \mathrm{M} \mathrm{NH} \mathrm{N}_{2}$-DTG (open circles). One curve depicts 5-HTevoked contractions assayed in the presence of $10 \mu \mathrm{M}(+)$ SKF 10,047 (crosses). B, 2-Methyl-5-HT-evoked contractions of the LMMP and the noncompetitive inhibition of this effect by DTG. Amplitude of contractions evoked by 2-methyl-5-HT (filled squares) increased in monophasic concentration-dependent manner to reach a plateau not statistically different from that of 5-HT (filled circles) obtained in the same preparation. DTG at $500 \mathrm{~nm}$ (open triangles), $1 \mu \mathrm{M}$ (open circles), $3 \mu \mathrm{M}$ (open diamonds), and $8 \mu \mathrm{M}$ (open squares) noncompetitively antagonized the 2-methyl5-HT-evoked contractions.

presence of the specific $5-\mathrm{HT}_{2}$ antagonist ketanserin at $1 \mu \mathrm{M}$. In the presence of $1 \mu \mathrm{M}$ ketanserin, the following compounds did not affect the 5-HT concentration-response curve: the nonselective $5-\mathrm{HT}_{1}$ and $5-\mathrm{HT}_{2}$ antagonist methiothepin at $1 \mu \mathrm{M}$, the $5-\mathrm{HT}_{1 \mathrm{~A}}$ and $5-\mathrm{HT}_{2}$ antagonist spiperone at $1 \mu \mathrm{M}$ and the selective 5-HT ${ }_{1 \mathrm{P}}$ antagonist 5-HTP-DP at $10 \mu \mathrm{M}$. In the presence of $1 \mu \mathrm{M}$ methysergide, the 5-HT response was competitively shifted to the right by increasing concentrations of the selective $5-\mathrm{HT}_{3}$ receptor-selective antagonist ICS 205-930, and analysis of the data in the method of Arunlakshana and Schild (1959) gave a straight line with slope $1.1 \pm 0.2$ and $\mathrm{pA}_{2}$ value of $8.1 \pm 0.2$

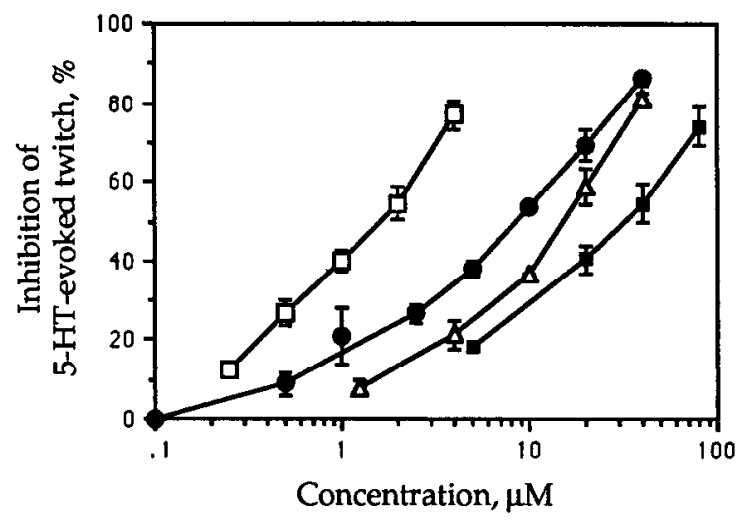

Figure 5. Inhibition of the 5-HT-evoked twitch by sigma receptor ligands. The ability of each sigma receptor ligand at a given concentration to suppress the maximal amplitude of the 5-HT-evoked twitch was determined with a 3-concentration-response curve paradigm as described in Materials and Methods. For example, as can be seen in Figure $4 A$, the maximum twitch evoked by $5-\mathrm{HT}$ in the presence of $4 \mu \mathrm{M} \mathrm{NH}_{2^{-}}$ DTG was $80 \%$ of the maximum obtained in its absence; therefore, 4 $\mu \mathrm{M} \mathrm{NH}-\mathrm{DTG}$ inhibited the 5-HT-evoked twitch by $20 \%$, as is plotted here. Curves for each sigma ligand were constructed in which each data point represents a single 3-concentration-response paradigm experiment. AdIpG (open squares), DTG (filled circles), $\mathrm{NH}_{2}$-DTG (open triangles), and DPG (filled squares); similar curves were obtained for haloperidol, BMY 14802, and AdTG (data not shown).
( $n=8$, data not shown; see Richardson et al., 1985, figure $2 c$ ); these values are in close agreement with those previously published: $\mathrm{pA}_{2}=8.1 \pm 0.2$ (Buchheit et al., 1985) and $7.85 \pm 0.1$ (Richardson et al., 1985). ICS 205-930 also competitively antagonized 5-HT contractions in the presence of $1 \mu \mathrm{M}$ ketanserin in place of methysergide. These observations indicate that 5 -HT's contractile response in the LMMP is mediated primarily by $5-\mathrm{HT}_{3}$ receptors (see Bradley et al., 1986).

Sigma receptor ligands were found to affect the 5-HT-evoked contractions. DTG inhibited the 5-HT-evoked contractions in a concentration-dependent manner with an $\mathrm{IC}_{50}$ of $9.0 \mu \mathrm{M}$ (Table 1, Fig. 5); the inhibition of 5-HT-evoked contractions by DTG was noncompetitive in that it could not be overcome by increasing 5-HT concentrations. The disubstitutcd guanidines AdIpG, AdTG, $\mathrm{NH}_{2}$-DTG, and DPG and haloperidol and BMY 14802 similarly inhibited the 5 -HT-evoked contractions in a noncompetitive manner (Figs. $4 A, 5$; Table 1 ). The sigma receptor inactive congeners Bridge-DPG and DMG did not affect the 5-HT-evoked contractions. (+)SKF 10,047 at $10 \mu \mathrm{M}$ shifted the 5-HT concentration-response curve 3.5-fold to the left (Fig. 4A). DTG noncompetitively blocked the 2-methyl-5-HT-evoked contractions with an $\mathrm{IC}_{50}$ of $2.8 \mu \mathrm{M}$ (interpolated from Fig. $4 B$ ). The inhibition of contractions evoked by 5 -HT and by 2 -methyl-5-HT could be completely abolished by sigma receptor ligands (e.g., Fig. 4B, open squares).

\section{Correlation of binding affinity with bioactivity of sigma receptor active drugs}

The $\mathrm{IC}_{50}$ values for most, but not all, of the sigma ligands in inhibiting the elcctrically cvoked contractions of the guinea pig ileum LMMP preparation were highly correlated with their ability to displace ${ }^{3} \mathrm{H}$-DTG from sigma receptors in guinea pig hrain homogenates. The highest correlation was found for the 10 sigma receptor-active DTG congeners $(r=0.98, p<0.0001$; Fig. $6 A$, filled circles). Note that the 2 sigma receptor-inactive congeners did not inhibit the electrically evoked contractions (Table 1). A high correlation was also found when numerous other chemically diverse sigma ligands were taken into account, in- 
$\mathbf{\Lambda}$

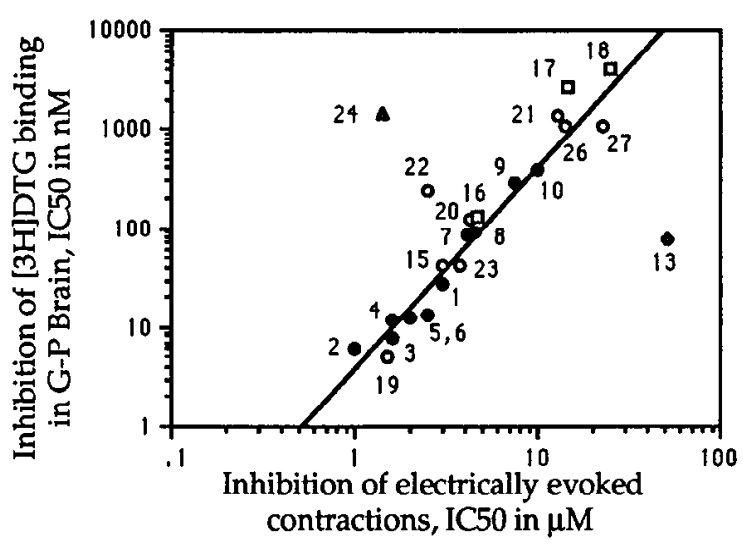

B

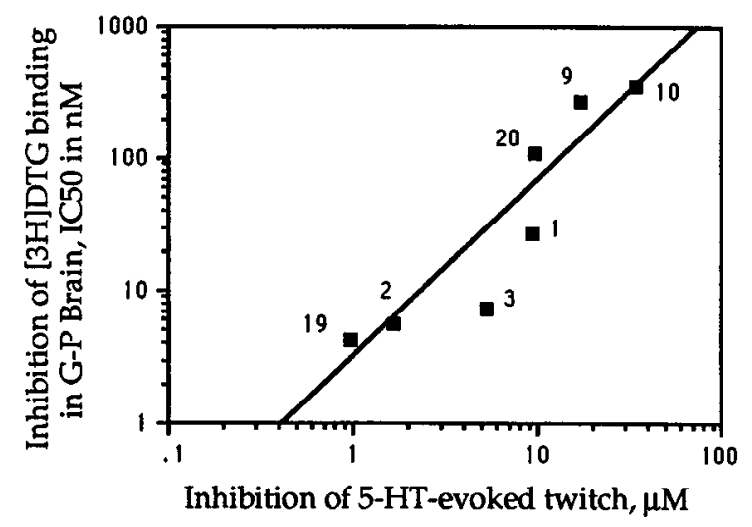

Figure 6. A, Corrclation of sigma receptor ligand binding affinity and potency in inhibiting the electrically evoked twitch in the LMMP. Sigma receptor binding and potency in inhibiting the electrically evoked twitch were assessed as described in Table 1 and Materials and Methods. Correlation line is derived from regression analysis for compounds 1-10, namely, DTG and its sigma receptor-active congeners $($ filled circles; $r=$ $0.98, p<0.0001$ ). Eight other compounds with high sigma receptor affinity (open circles; 15, 19-23, 26, 27) also correlated well independently $(r$ $=0.89, p<0.01)$ and in conjunction with the DTG congeners $(r=0.93, p<0.0001, n=18)$. (-)Benzomorphans (open squares, 16-18) also correlated with above aggregate $(r=0.95, p<0.0001, n=21)$. Two sigma receptor ligands, chlorpromazine (24, open triangle $)$ and $(+) 3-\mathrm{PPP}(13$, open diamond) were distant from the regression line generated by the DTG congeners. All numbers as in Table 1 . $B$, Correlation of sigma receptor ligand binding affinity and potency in antagonizing the 5-HT-evoked contractions in the LMMP. Sigma receptor binding affinity was assessed as described in Table 1 and Materials and Methods. Antagonism of the 5-HT-evoked contractions was assessed as shown in Table 1 and Figures $4 A$ and 5 and as described in Materials and Methods. The inhibition of 5-HT-evoked contractions by 5 DTG congeners (DTG,1; AdIpG,2; AdTG,3; $\mathrm{NH}_{2}$-DTG,9; DPG,10) and haloperidol (19) and BMY $14802(20)$ correlated well with their sigma receptor affinity $(r=0.91, p<0.01)$.

cluding the typical antipsychotics haloperidol and perphenazine, the novel antipsychotics BMY 14802, rimcazole, and tiospirone, the arylcyclohexylamines PCP and TCP, and the benzomorphan $(+)$ pentazocine; these 8 compounds alone also correlated well ( $r=0.89, p<0.01 ;$ Fig. $6 \mathrm{~A}$, open circles), as did the aggregate when they were included with the DTG congeners $(r=0.93, p$ $<0.0001, n=18$ ). Additionally, under conditions in which opioid receptors were blocked, the bioactivity of the (-)benzomorphans pentazocine, cyclazocine, and SKF 10,047 also correlated well with their sigma receptor binding (Fig. 6A, open squares; aggregate $r=0.95, p<0.0001, n=21$ ). The compounds that correlated poorly were chlorpromazine, having a higher potency in the bioassay that would be expected from its binding affinity, and $(+)$ and (-)3-PPP, both displaying lower potency in the bioassay compared with their binding affinities. The benzomorphans $(+)$ cyclazocine and $(+)$ SKF 10,047 potentiated the contractions and therefore were not included in the correlation. There was also a high correlation for 5 DTG congeners and for haloperidol and BMY 14802 to inhibit 5-HT-evoked contractions compared with their sigma receptor affinity $(r=0.91$, $p<0.01$; Fig. $6 B$ ).

\section{Discussion}

\section{Sigma receptor bioactivity}

The cardinal finding of this study is that DTG and its sigma receptor-active congeners inhibit electrically or 5-HT-evoked contractions of the LMMP preparation by a neuronal mechanism and that the potency of these drugs in the bioassays is highly correlated with their sigma receptor binding affinity in guinea pig brain membrane homogenates. Sigma receptor binding sites have been shown to be present in the myenteric plexus of the guinea pig ileum (Roman et al., 1988). Thus, our results strongly suggest that the inhibitory actions of the DTG conge- ners on 5-HT - or electrically evoked contractions of the LMMP are mediated by sigma receptors.

The hypothesis that the DTG congeners act in the LMMP at sigma receptors is supported by several observations. First, similar results were obtained using 2 different stimulation paradigms - by electrical pulses and by 5 -HT - and high correlations were found for each paradigm. Second, 2 DTG congeners, BridgeDPG and DMG, that lack sigma receptor binding affinity also lacked sigma receptor bioactivity; because of their similar structures, $\mathrm{p} K_{a}$ 's, and molecular weights to active congeners, these control compounds presumably also share their nonspecific confounding effects. Third, antagonists to adrenergic, dopaminergic, and opioid receptors were inactive in altering the sigma receptor bioactivity of DTG. Fourth, the bioactivity of a broad range of sigma receptor ligands with diverse chemical structures also correlated well with sigma receptor binding affinity, both independently of the DTG congeners and when grouped with them. Fifth, compounds with binding affinities over a range of 3 orders of magnitude correlated well with respect to their sigma receptor bioactivity. It is important to note, however, that the slope of this correlation line is significantly greater than unity; i.e., a 10-fold increase in binding affinity yields a less than 10fold increase in bioactivity. The basis of this discrepancy is not known, in part because the molecular and cellular correlates of sigma receptor activation are not known. It is of interest that preliminary reports demonstrate that sigma receptor ligands negatively modulate phosphoinositide metabolism in rat brain (Bowen et al., 1988a; Kirschner et al., 1988); this effect resembles the inhibition of LMMP contractions in that it occurred only under agonist-stimulated conditions, the effective concentrations for ligands common to both studies were similar, and the ability to inhibit phosphoinositide metabolism was highly correlated with binding affinity with a slope significantly greater 
than one (greater difference in affinity than bioactivity). Negative modulation of agonist-stimulated phosphoinositide turnover has previously been shown for D2 receptors on lactotrophs (Enjalbert et al., 1986) and NMDA receptors in hippocampus (Baudry et al., 1987).

DTG inhibited electrically evoked contractions of the LMMP at concentrations approximately 100 times its affinity for CNS sigma receptors; this difference in absolute potency is shared by the other sigma receptor ligands. The disparity is particularly surprising in that agonists at opioid receptors are active in the LMMP at potencies near their binding affinity for mu and kappa sites. It is possible that the bioavailability of DTG and its congeners is impaired in intact LMMP strips. Alternately, the myenteric sigma receptors may have lower affinities for these compounds relative to central sites; preliminary data by Roman et al. (1988) suggest that sigma receptors in the LMMP possess similar properties as those in the CNS, and the binding of the selective sigma receptor radioligand ${ }^{3} \mathrm{H}-\mathrm{DTG}$ in the LMMP is currently being investigated.

A further consideration raised by these data is whether sigma receptor-active compounds can be identified as agonists or antagonists. All disubstituted guanidines tested and most other compounds inhibited the LMMP contractions in accordance with their sigma receptor binding affinity. The sigma receptor active benzomorphans $(+)$ SKF 10,047 and $(+)$ cyclazocine potentiated the contractions of the LMMP preparation, acting opposite to all other sigma ligands tested. It is not known whether these 2 drugs acted through sigma receptors to potentiate the contractions or through an unidentified mechanism. Their effects were blocked by TTX, thus apparently neuronal, but were not affected by DTG. The mixed dopamine/sigma receptor ligands $(+)$ and $(-) 3-$ PPP were notably less potent in the bioassay compared with DTG. No compound yet tested has demonstrated the ability to specifically antagonize the responses of the sigma receptor ligands.

Sigma receptor ligands were found to inhibit LMMP contractions evoked by the bath application of 5-HT. The contractile effect of 5-HT in this preparation could be ascribed to an effect on the neurons of the myenteric plexus because it was blocked by TTX and was unaffected by the presence of antagonists of $5-\mathrm{HT}_{2}$ receptors located on the smooth muscle cells. The myenteric plexus, however, contains a diverse population of neurons, and the experimentally measured parameter (tension produced by smooth muscle contraction) reflects only the final common output via excitatory cholinergic neurons of the complex myenteric circuitry. Interpretation is further complicated in that 5-HT has multiple effects on myenteric neurons and acts on more than one type of neuronal receptor. Three distinct effects of 5-HT on myenteric neurons have been characterized in terms of their inhibition by specific receptor antagonists: a 5 - $\mathrm{HT}_{1 \mathrm{~A}}$-mediated hyperpolarization that is blocked by spiperone (Galligan et al., 1988); a 5- $\mathrm{HT}_{\mathrm{PP}}$-mediated slow depolarization that is blocked by 5-HTP-DP (Takaki et al., 1985; Mawe et al., 1986); and a 5- $\mathrm{HT}_{3}$-mediated fast depolarization that is blocked by ICS 205-930 (Mawe et al., 1986). The contribution of activation of these 5-HT receptor types to the contractile response was assessed by these specific antagonists in the LMMP preparation. Spiperone and 5-HTP-DP at concentrations that blocked the effect of 5-HT on myenteric neurons did not affect the 5-HT contractile effect on the LMMP, suggesting that activation of $5-\mathrm{HT}_{1 \mathrm{~A}}$ and $5-\mathrm{HT}_{1 \mathrm{P}}$ receptors does not significantly contribute to the contractile response. LMMP contractions were, however, competitively antagonized by ICS 205-930, and Schild analysis of this effect yielded linear slope and a $\mathrm{pA}_{2}$ value that closely matched previously published results using this preparation. These results suggest that $5-\mathrm{HT}$ acts primarily at $5-\mathrm{HT}_{3}$ receptors to contract the LMMP. The lack of contractile effects of selective $5-\mathrm{HT}_{1 \mathrm{~A}}$ agonists and the ability of the $5-\mathrm{HT}_{3}$ agonist 2-methyl-5-HT to contract the LMMP to the same maximum tension as 5-HT in the same strips further supports this hypothesis. These data fully meet the criteria proposed by Bradley et al. (1986) for characterization of 5- $\mathrm{HT}_{3}$-mediated responses, as do the results obtained by Buchheit et al. (1985) and Richardson et al. (1985) using the same preparation. Kilbinger and Pfeuffer-Friederich (1985) reached a similar conclusion by examining the efflux of tritiated ACh from preloaded LMMP in response to 5-HT.

Thus, the LMMP contractile response evoked by $5-\mathrm{HT}$ is mediated primarily by $5-\mathrm{HT}_{3}$ receptors. Sigma receptor ligands were found to inhibit this response in a noncompetitive manner. Numerous possible mechanisms can be proposed whereby sigma receptor ligands interfere with the chain of events initiated by 5 -HT's binding to $5-\mathrm{HT}_{3}$-recognition sites and completed by the release of $\mathrm{ACh}$ from cholinergic myenteric neurons. One possible mechanism is that sigma receptor ligands block the channel opened by 5-HT's activation of 5- $\mathrm{HT}_{3}$ receptors, analogous to MK-801's blockade of the channel opened by glutamate's activation of NMDA receptors. That this does not occur was demonstrated by intracellular recordings performed in myenteric plexus neurons in which depolarization following $5-\mathrm{HT}_{3}$ receptor activation was not affected in the presence of DTG (Galligan et al., 1989). A second possible mechanism is that sigma receptors act to uncouple excitation from ncurotransmitter release directly on cells that express both sigma and $5-\mathrm{HT}_{3}$ receptors. The majority of myenteric S/type I neurons, a subset of which are the cholinergic excitatory neurons that release $\mathrm{ACh}$ to contract the longitudinal smooth muscle (Furness and Costa, 1987), demonstrate 5- $\mathrm{HT}_{3}$-mediated depolarizations to 5-HT (Galligan et al., 1989); thus, sigma receptor activation may interfere with excitation-neurotransmitter release coupling directly in these cells. The negative modulation of phosphoinositide metabolism by sigma receptor ligands could provide a mechanism for the observed inhibition of ACh release (Bowen et al., 1988a). It is not known, however, whether the cholinergic motor neurons are among those $\mathrm{S} /$ type I cells that possess $5-\mathrm{HT}_{3}$ receptors, and $5-\mathrm{HT}_{3}$-mediated responses to $5-\mathrm{HT}$ have also been observed in most AH/type II cells (Takaki et al., 1985; Mawe et al., 1986). If myenteric neurons with 5- $\mathrm{HT}_{3}$ receptors synapse with cells with sigma receptors that either are, or eventually activate, the cholinergic final motor neurons, then $5-\mathrm{HT}$ induced contractions would be antagonized without sigma receptors having either to affect $5-\mathrm{HT}_{3}$ receptor activation or transmitter release by the myenteric S/type I neurons themselves. The mechanism that underlies the inhibition of $\mathrm{ACh}$ release by DTG and other sigma receptor ligands in the myenteric plexus can only be established by careful electrophysiologic and biochemical studies; the series of disubstituted guanidine compounds described here may prove useful in this pursuit. $5-\mathrm{HT}_{3}$ receptors have recently been identified in the brain (Kilpatrick et al., 1987) and shown to mediate rapid synaptic CNS neurotransmission (Yakel and Jackson, 1988). It will be of interest to see if sigma receptor activation in the brain-as in the ileum-results in the inhibition of 5- $\mathrm{HT}_{3}$-mediated or other rapid excitatory responses. 
Opioid receptor agonist drugs also inhibit electrically and 5-HT-stimulated $\mathrm{ACh}$ release in the ileum (Gaddum and Picarelli, 1957; Leslie, 1987). However, it is clear that sigma receptor-mediated inhibition is separate from opioid receptormediated inhibition since the sigma ligands were not antagonized by naloxone and sigma receptor-mediated inhibition was not altered in ilea that had been treated with the irreversible opioid receptor antagonist B-CNA. On the other hand, sigma receptor activation clearly has the same functional result as opioid receptor activation. This is most clearly illustrated by the effects of the opioid active (-)isomer of pentazocine on the electrically stimulated ileum. In the absence of naloxone, $(-)$ pentazocine potently inhibited the electrically induced twitch response. Naloxone shifted the dose-response curve of $(-)$ pentazocine to the right, suggesting that the low-dose effects of $(-)$ pentazocine were mediated by opioid receptors. In ilea in which opioid receptors had been inactivated by the irreversible opiate antagonist B-CNA, (-)pentazocine still caused a dosedependent inhibition of the twitch response, presumably by interaction with sigma receptors. Given these opioid receptorlike properties of sigma receptors, it is important to note recent results from drug discrimination studies performed by Holtzman (1989) showing that mu and kappa opioid receptor agonists were able to substitute for DTG in rats trained to discriminate DTG from saline. It was shown in that study that the DTGlike discriminative stimulus control of behavior by the mu and kappa agonists was mediated by a naloxone-sensitive opioid receptor, while the discriminative stimulus control of behavior by DTG was naloxone insensitive. Our results show a naloxoneinsensitive effect of DTG on stimulated ACh release in the ileum that mimics that of opioid receptor activation. This opioid-like effect of sigma receptor activation by DTG may well explain why mu and kappa opioid receptor agonists fully substitute for DTG in drug-discrimination studies.

The actions of PCP and TCP in inhibiting the electrically evoked contractions of the LMMP have previously been reported (Gintzler et al., 1982) and were ascribed to specific PCP receptors in the LMMP. However, several lines of evidence suggest that PCP and TCP act in the LMMP at sigma rather than PCP receptors. First, the highly selective PCP receptor ligand MK-801 was virtually inactive at inhibiting the electrically evoked contractions, although it has higher affinity than PCP and TCP for the PCP receptor and is more potent that PCP and TCP in numerous CNS effects of the PCP receptor (Wong et al., 1986; Kemp et al., 1987). Second, the potency of PCP and TCP to inhibit electrically evoked contractions correlated well with their sigma receptor binding affinity. Third, activity at NMDA sites in the LMMP as demonstrated by application of exogenous glutamate are blocked in the presence of the Krebs buffer $\mathrm{Mg}^{2+}$ concentration used in these studies (1.17 mM; see Luzzi et al., 1988). Thus, DTG, PCP, and TCP may act via a common mechanism in the LMMP, namely, the sigma receptor. This finding may be useful in interpreting drug-discrimination studies recently performed by Holtzman (1989), in which rats trained to distinguish PCP from saline generalized dose dependently and completely to DTG as did rats trained to DTG did for PCP.

Recent studies have provided evidence that certain sigma receptor-active drugs such as $(+) 3-P P P,(+)$ pentazocine, TCP, and $(+)$ SKF 10,047 can augment electrically stimulated contractions of the mouse and guinea pig vasa deferentia by a neuronal mechanism (Campbell et al., 1987; Vaupel and Su, 1987).
The site of action for these effects is uncertain in the absence of any clear correlation between bioactivity and binding affinity at sigma receptors and radioligand binding studies to demonstrate the presence of sigma sites. It remains to be determined if there are functional sigma receptors in the vas deferens, as has been demonstrated here for the guinea pig ileum LMMP preparation.

\section{Sigma receptors and centrally mediated effects}

Until now, sigma receptors were defined as specific and anatomically highly localized binding sites in limbic and sensorimotor structures of the brain. No function was assigned to these sites. However, it has been suggested that sigma sites may play an important role in the action of psychotropic drugs (Deulch et al., 1988; Snyder and Largent, 1989). Some novel nondopaminergic antipsychotic drug candidates such as BMY 14802 , rimcazole and remoxipride have been shown to bind selectively to sigma receptors (Ferris et al., 1986; Largent et al., 1988; Taylor and Dekleva, 1988). The common mode of action of all typical and novel antipsychotics tested in the ileum suggests that sigma receptor-mediated inhibition of neurotransmitter release could be responsible for the antipsychotic properties that these drugs have in common. This mechanism if active in modulating dopamine release from mesolimbocortically projecting ventral tegmental neurons would provide a conceptual basis for the antipsychotic properties of selective sigma ligands such as BMY 14802, rimcazole, and remoxipride. Three recent observations are of particular interest in this light. First, sigma receptors and $\mathrm{D}_{2}$ receptors have been shown to share dense concentrations in an anatomically discrete subdivision of the cat's substantia nigra pars compacta, the densocellular zone (Graybiel et al., 1989). Second, BMY 14802 in electrophysiological studies has been shown to modulate dopaminergic neurotransmission in ventral tegmental neurons by a nondopaminergic (presumably sigma-mediated) mechanism (Wachtel and White, 1988). Third, the sigma receptor-selective antipsychotic rimcazole has been shown to block both behavioral hyperactivity and excitation of ventral tegmental dopamine neurons induced by (+)SKF 10,047 (Ceci et al., 1988).

However, it remains to be seen whether inhibitory action in the ileum combined with high sigma receptor binding activity is predictive of a drug's antipsychotic activity in vivo. This question can be answered by testing a wide variety of selective sigma receptor ligands (such as our DTG congeners) in the ileum bioassays followed by evaluation of the drugs in animal tests that are predictive of antipsychotic activity. Although the receptor sclectivity of the DTG congeners has not been firmly established, they have poor affinity $\left(\mathrm{IC}_{50}\right.$ values $\left.>1 \mu \mathrm{M}\right)$ for the $\mathrm{PCP}$ receptor and for opioid (unpublished observations), serotinergic (S. Peroutka, personal communication), dopaminergic, and glutamatergic receptors (J. C. Fisher, personal communication).

In summary, we have demonstrated that there are functional sigma receptors in the LMMP preparation and that sigma receptor ligands act to inhibit electrically or 5-HT-stimulated ACh release by an opioid receptor-independent mechanism. Furthermore, we have synthesized and characterized 9 novel DTG congeners with potent sigma receptor binding and bioactivity, as well as 2 chemically related but inactive control compounds. The bioassay system and the novel drugs described here should be useful tools to clarify the role of sigma receptors in the modulation of neurotransmitter release. 


\section{References}

Adam-Vizi, V., and E. S. Vizi (1978) Direct evidence of acetylcholine releasing effect of serotonin in the Auerbach plexus. J. Neural Transm. 42: $127-138$.

Aniline, O., and F. N. Pitts, Jr. (1982) Phencyclidine (PCP): A review and perspectives. CRC Crit. Rev. Toxicol. 10: 145-177.

Anis, N. A., S. C. Berry, N. R. Burton, and D. Lodge (1983) The dissociative anaesthetics, ketamine and phencyclidine, selectively reduce excitation of central mammalian neurons by $\mathrm{N}$-methyl-aspartate. Br. J. Pharmacol. 79: 565-575.

Arunlakshana, O., and H. O. Schild (1959) Some quantitative uses of drug antagonists. Br. J. Pharmacol. 14: 48-58.

Baudry, M., J. Evans, and G. Lynch (1987) Excitatory amino acids inhibit stimulation of phosphotidylinositol metabolism by aminergic agonists in hippocampus. Nature 319: 329-331.

Bowen, W. D., B. D. Kirschner, A. H. Newman, and K. C. Rice (1988a) Sigma-receptors negatively modulate agonist-stimulated phosphoinositide metabolism in rat brain. Eur. J. Pharmacol. 149:399-400.

Bowen, W. D., J. M. Walker, A. G. Yashar, R. R. Matsumoto, F. O. Walker, and J. F. Lorden (1988b) Altered haloperidol-sensitive sigma receptors in the genetically dystonic (dt) rat. Eur. J. Pharmacol. 147: 153-154

Bradley, P. B., G. Engel, W. Geniuk, F. R. Fozard, P. P. A. Humphrey, D. N. Middlemiss, E. J. Mylecharane, B. P. Richardson, and P. R. Saxena (1986) Proposals for the classification and nomenclature of functional receptors for 5-hydroxytryptamine. Neuropharmacology 25: 563-576.

Buchheit, K.-H., G. Engel, E. Mutschlcr, and B. Richardson (1985) Study of the contractile effect of 5-hydroxytryptamine in the isolated longitudinal muscle strip from guinea-pig ileum. Naunyn-Schmiedeberg's Arch. Pharmacol. 329: 36-41.

Campbell, B. G., D. H. Bobker, F. M. Leslie, I. N. Mefford, and E. Weber (1987) Both the sigma receptor-specific ligand (+)3-PPP and the PCP receptor-specific ligand TCP act in the mouse vas deferens via augmentation of electrically evoked norepinephrine release. Eur. J. Pharmacol. 138: 447-449.

Ceci, A., M. Smith, and E. D. French (1988) Activation of the A mesolimbic system by the sigma-receptor agonist ( + SKF 10,047 can be blocked by rimcazole, a novel putative antipsychotic. Eur. J. Pharmacol. 154: 53-57.

Deutch, S. I., A. Weizman, M. E. Goldman, and J. M. Morihisa (1988) The sigma receptor: A novel site implicated in psychosis and antipsychotic drug efficacy. Clin. Neuropharmacol. 11: 105-119.

Downes, C. P., P. E. Lewis, and M. A. Stone (1986) A comparison of the binding of sigma opioids and phencyclidine, and the interaction with antipsychotic drugs in rat brain membranes. Br. J. Pharmacol. 88: 231-237.

Enjalbert, A., F. Sladeczek, G. Guillon, P. Bertrand, C. Shu, J. Epelbaum, A. Garcia-Sainz, S. Jard, C. Lombard, C. Kordon, and J. Bockaert (1986) Angiotensin II and dopamine modulate both cAMP and inositol phosphate productions in anterior pituitary cells. J. Biol. Chem. 261: 4071-4075.

Ferris, R. M., F. L. M. Tang, K.-J. Chang, and A. Russell (1986) Evidence that the potential antipsychotic agent rimcazole (BW 234U) is a specific, competitive antagonist of sigma sites in brain. Life Sci. 35: 2329-2337.

Furness, J. B., and M. Costa (1987) The Enteric Nervous System Churchill Livingstone, Edinburgh.

Gaddum, J. H., and Z. P. Picarelli (1957) Two kinds of tryplamine receptors. Br. J. Pharmacol. 12: 323-328.

Galligan, J. J., A. Surprenant, M. Tonini, and R. A. North (1988) Differential localization of $5-\mathrm{HT}_{1}$ receptors on myenteric and submucosal neurons. Am. J. Physiol. 255: G603-G611.

Galligan, J. J., B. G. Campbell, M. P. Kavanaugh, E. Weber, and R. A. North (1989) DTG (1,3-di[2-tolyl]guanidine) blocks nicotinic response in guinea pig myenteric neurons. J. Pharmacol. Exp. Ther. (in press).

Gintzler, A. R., R. S. Zukin, and S. R. Zukin (1982) Effects of phencyclidine and its derivatives on enteric neurons. Br. J. Pharmacol. 75: 261-267.

Graybiel, A. M., M.-J. Besson, and E. Weber (1989) Neurolepticsensitive binding sites in the nigrostriatal system: Evidence for differential distribution of sigma sites in the substantia nigra, pars compacta of the cat. J. Neurosci. 9: 326-338.
Haertzen, C. A. (1970) Subjective effects of narcotic antagonists cyclazocine and nalorphine on the Addiction Research Center Inventory (ARCI). Psychopharmacologia (Berl.) 18: 366-377.

Holtzman, S. G. (1985) Discriminative stimulus properties of opioids that interact with mu, kappa and PCP/sigma receptors. In Behavioral Pharmacology: The Current Status, L. S. Seiden and R. L. Balster, eds., pp. 131-147, Liss, Ann Arbor, MI.

Holtzman, S. G. (1989) Opioid- and phencyclidine-like discriminative effects of ditolylguanidine (DTG), a selective sigma agonist. J. Pharmacol. Exp. Ther. 248: 1054-1062.

Huettner, J. E. and B. P. Bean (1988) Block of N-methyl-D-aspartateactivated current by the anticonvulsant MK-801: Selective binding to open channels. Proc. Natl. Acad. Sci. USA 85: 1307-1311.

Katz, J. L., R. D. Spealman, and R. D. Clark (1985) Stereoselective behavioral effects of $\mathrm{N}$-allylnormetazocine in pigeons and squirrel monkeys. J. Pharmacol. Exp. Ther. 232: 452-461.

Keats, A. S., and J. Telford (1964) Narcotic antagonists as analgesics. In Molecular Modification in Drug Design, R. F. Gould, ed., Advances in Chemistry Series, no. 45, American Chemical Society, Washington, DC.

Kemp, J. A., A. C. Foster, and E. H. F. Wong. (1987) Non-competitive antagonists of excitatory amino acid receptors. Trends Neurosci. 10: 294-298.

Kilbinger, H., and I. Pfeuffer-Friederich (1985) Two types of receptors for 5-hydroxytryptamine on the cholinergic nerves of the guinea-pig myenteric plexus. Br. J. Pharmacol. 85: 529-539.

Kilpatrick, G. J., B. J. Jones, and M. B. Tyers (1987) Identification and distribution of $5-\mathrm{HT}_{3}$ receptors in rat brain using radioligand binding. Nature 330: 746-748.

Kirschner, B. N., S. B. Hellewell, A. H. Newman, K. C. Rice, and W. D. Bowen (1988) Sigma receptors negatively modulate agonist stimulated phosphoinositide metabolism in brain synaptoneurosomes. Soc. Neurosci. Abstr. 14: 86

Largent, B. L., A. L. Gundlach, and S. H. Snyder (1984) Psychotomimetic opiate receptors labeled and visualized with $(+)-\left[{ }^{3} \mathrm{H}\right] 3-(3-$ hydroxyphenyl)-N-(1-propyl)piperidine. Proc. Natl. Acad. Sci. USA 81: 5618-5621.

Largent, B. L., A. L. Gundlach, and S. H. Snyder (1986) Pharmacological and autoradiographic discrimination of sigma and phencyclidine receptor binding sites in brain with $(+)-\left[{ }^{3} \mathrm{H}\right] \mathrm{SKF} 10,047,(+)-$ $\left[{ }^{3} \mathrm{H}\right]-3-\left[3\right.$-hydroxyphenyl]-N-(1-propyl)piperidine and $\left[{ }^{3} \mathrm{H}\right] 1-[1-(2-$ thienyl)cyclohexyl]piperidine. J. Pharmacol. Exp. Ther. 238: 739748.

Largent, B. L., H. Wikstrom, A. M. Snowman, and S. H. Snyder (1988) Novel antipsychotic drugs share high affinity for sigma receptors. Eur. J. Pharmacol. 155: 345-347.

Leslie, F. (1987) Methods used for the study of opioid receptors. Pharmacol. Rev. 39: 197-249.

Luzzi, S., L. Zilletti, S. Franchi-Micheli, A. M. Gori, and F. Mononi (1988) Agonists, antagonists and modulators of excitatory amino acid receptors in guinea-pig myenteric plexus. Br. J. Pharmacol. 95: $1271-1277$

Maragos, W. F., J. B. Penney, and A. B. Young (1988) Anatomic correlation of NMDA and ${ }^{3} \mathrm{H}-\mathrm{TCP}$-labeled receptors in rat brain. $\mathrm{J}$. Neurosci. 8:493-501.

Mawe, G. M., T. A. Branchek, and M. D. Gershon (1986) Peripheral neural scrotonin receptors: Identification and charactcrization with specific antagonists and agonists. Proc. Natl. Acad. Sci. USA 83: 9799-9803

Quirion, R., R. Chicheportiche, P. C. Contreras, K. M. Johnson, D. Lodge, S. W. Tam, J. H. Woods, and S. R. Zukin (1987) Classification and nomenclature of phencyclidine and sigma receptor sites. Trends Neurosci. 10: 444-446.

Richardson, B. P., G. Engel, P. Donatsch, and P. A. Stadler (1985) Identification of serotonin M-receptor subtypes and their specific blockade by a new class of drugs. Nature 316: 126-131.

Roman, F., X. Pascaud, D. Vauche, and J.-L. Junien (1988) Evidence for a non-opioid sigma binding site in the guinea-pig myenteric plexus. Life Sci. 42: 2217-2222.

Sircar, R., R. Nichtenhauser, J. R. Ieni, and S. R. Zukin (1986) Characterization and autoradiographic visualization of ( 1 )-[ $\left.{ }^{3} \mathrm{H}\right]$ SKF 10,047 binding in rat and mouse brain: Further evidence of phencyclidine/ "sigma opiate" receptor commonality. J. Pharmacol. Exp. Ther. 237; 681-688.

Snyder, S. H. (1980) Phencyclidine. Nature 285: 355-356. 
Snyder, S. H., and B. L. Largent (1989) Receptor mechanisms in antipsychotic drug action: Focus on sigma receptors. J. Neuropsychiatry $1: 7-15$.

Sonders, M. S., J. F. W. Keana, and E. Weber (1988) Phencyclidine and psychotomimetic sigma opiates: Recent insights into their biochemical and physiological sites of action. Trends Neurosci. 11:3740.

$\mathrm{Su}, \mathrm{T} . \mathrm{P}$. (1982) Evidence for sigma opioid receptor: Binding of [ $\left.{ }^{3} \mathrm{H}\right] \mathrm{SKF}$ 10,047 to etorphin-inaccessible sites in guinea pig brain. J. Pharmacol. Exp. Ther. 223: 284-290.

Surprenant, A., and J. Crist (1988) Electrophysiological characterization of functionally distinct 5-hydroxytryptamine receptors on guineapig submucous plexus. Neuroscience 24: 283-295.

Takaki, M., T. Branchek, H. Tamir, and M. D. Gershon (1985) Specific antagonism of enteric neural serotonin receptors by dipeptides of 5-hydroxytryptophan: Evidence that serotonin is a mediator of slow synaptic excitation in the myenteric plexus. J. Neurosci. 5: 17691780.

Tam, S. W., and L. Cook (1984) Sigma opiates and certain antipsychotic drugs mutually inhibit $(+)-\left[{ }^{3} \mathrm{H}\right] \mathrm{SKF} 10,047$ and $\left[{ }^{3} \mathrm{H}\right]$ haloperidol binding in guinea pig brain membranes. Proc. Natl. Acad. Sci. USA 81: 5618-5621.

Taylor, D. P., and J. Dekleva (1988) BMY 14802: A potential antipsychotic agent that selectively binds to sigma receptors. In Sigma and Phencyclidine-like Compounds as Molecular Probes in Biology, E. F. Domino and J.-M. Kamenka, eds., pp. 345-355, NPP Books, Ann Arbor, MI.
Traynor, J. R., A. D. Corbett, and H. W. Kosterlitz (1987) Diprenorphine has agonist activity at opioid kappa-receptors in the myenteric plexus of the guinea-pig ileum. Eur. J. Pharmacol. 137: 85-89.

Vaupel, D. P., and Su, T. P. (1987) Both sigma receptors and PCP receptors potentiate contractions of the electrically stimulated guinea pig vas deferens. Eur. J. Pharmacol. 139: 125-127.

Wachtel, S. R., and F. J. White (1988) Electrophysiological effects of BMY 14802, a new potential antipsychotic drug, on midbrain dopamine neurons in the rat: Acute and chronic studies. J. Pharmacol. Exp. Ther. 244: 410-416.

Walker, J. M., R. R. Matsumoto, W. D. Bowen, D. L. Gans, K. D. Jones, and F. O. Walker (1988) Evidence for a role of haloperidolsensitive sigma-'opiate' receptors in the motor effects of antipsychotic drugs. Neurology 38: 961-965.

Weber, E., M. S. Sonders, M. Quarum, S. McLean, S. Pou, and J. F. W. Keana (1986) 1,3-Di(2-[5-3 H]tolyl)guanidine: A selective ligand that labels sigma-type receptors for psychotomimetic opiates and antipsychotic drugs. Proc. Natl. Acad. Sci. USA 83: 8784-8788.

Wong, E. H. F., J. A. Kemp, T. Priestly, A. R. Knight, G. N. Woodruff, and L. L. Iversen (1986) The anticonvulsant MK-801 is a potent N-methyl-D-aspartate antagonist. Proc. Natl. Acad. Sci. USA 83: 7104-7108.

Yakel, J. L., and M. B. Jackson (1988) 5- $\mathrm{HT}_{3}$ receptors mediate rapid responses in cultured hippocampus and a clonal cell line. Neuron 1 : $615-621$. 